\title{
TANTANGAN DOSEN PTKI DI ERA INDUSTRI 4.0
}

\author{
Kasinyo Harto \\ UIN Raden Fatah Palembang, Sumatera Selatan, Indonesia \\ masyo_71@yahoo.com
}

\begin{abstract}
Abstrak
Kajian ini bertujuan untuk mengungkap tentang tantangan dosen pada era Industri 4.0, khususnya bagi dosen di Perguruan Tinggi Keagamaan Islam (PTKI). Hasil dari kajian ini mengungkapkan bahwa dosen pada era industri 4.0 dituntut untuk memiliki empat kompetensi; pertama, mengetahui penggunaan digital serta penerapannya. Kedua, memiliki kompetensi kepemimpinan yang mampu mengarahkan mahasiswa memiliki pemahaman tentang teknologi. Ketiga, mempunyai kemampuan memprediksi dengan tepat arah gejolak perubahan dan langkah strategis menghadapinya. Keempat, mempunyai kompetensi dalam mengendalikan diri dari segala gejolak perubahan, dan mampu meenghadapinya dengan memunculkan ide, inovasi, serta kreativitas.
\end{abstract}

Kata kunci: Era Industri 4.0; Tantangan Dosen; PTKI;

\begin{abstract}
The current study intends to clarify the challenges of lecturers in the $4^{\text {th }}$ industrial era, especially those from Islamic Higher education. This study asserts that lecturers in the $4^{\text {th }}$ industrial era are required to have the four following competences. First, they should have a capability in utilizing digital tools and devices. Second, they should be able to encourage their students to master the use of technology. Third, they should be able to predict the future changes and ways to encounter them. Forth, they should be able to control themselves of the negative effect of the changes, and be able to face them by exploring new ideas, making innovations and creativity.

Keywords: The $4^{\text {th }}$ Industrial Era; Lecturers Challenges; Islamic Higher Education;
\end{abstract}

\section{PENDAHULUAN}

Saat ini, dunia mengalami perubahan yang berdampak begitu besar, dampak tersebut merupakan efek dari oleh adanya perkembangan dunia digital. Kemajuan ini oleh para ahli ilmu sosial disebut era disrupsi, era di mana seluruh sektor merasakan dampaknya, baik sektor ekonomi, politik maupun sektor pendidikan yang turut merasakan dampak dari transformasi digital. 
Transformasi digital dirasakan perlu untuk kemajuan dunia pendidikan di Indonesia. Dengan adanya transformasi digital, maka efisiensi biaya dan produktivitas, serta peningkatan mutu pendidikan akan bermuara pada sistem yang baik. Perguruan Tinggi merupakan salah satu sektor pendidikan yang selalu melakukan kajian serta riset dalam pengembangan masalah tersebut. Perguruan tinggi di Indonesia memandang perlu diadakannya suatu transformasi menuju era digital sebagaimana yang telah diterapkan oleh beberapa negara maju.

Menurut Fathur Rokhman Rektor Universitas Negeri Semarang dalam artikelnya mengugkapkan bahwa "era disrupsi ini merupakan masa dimana terdapat banyak gangguan yang disebabkan banyaknya perubahan yang terjadi dalam berbagai aspek kehidupan masyarakat, termasuk perubahan paradigma dan visi tentang dunia dan segala isinya" (Rokhman, 2018).

Renald Kasali berkesimpulan bahwa era disrupsi merupakan masa yang mengancam dan mempunyai tantangan berat pada kehidupan manusia, dan orang-orang yang tidak mampu beradaptasi dengan perubahan, tentu akan mengalami banyak kesulitan dalam mengarungi gelombang kehidupan sehari-hari yang penuh perubahan dan sarat persaingan (Kasali, 2018).

Untuk mengantisipasi era industrialisasi dalam dunia pendidikan tinggi di Indonesia, tanpa terkecuali pada Fakultas Ilmu Tarbiyah dan Keguruan sebagai sebuah institusi penyelenggara pendidikan, maka diperlukan sumber daya manusia dalam hal ini Dosen yang berkualitas, yang menguasai ilmu pengetahuan dan teknologi, serta mempunyai kreatifitas, inovatif, adaptif, serta berkepribadian. Makalah ini membahas bagaimana seharusnya Kualifikasi dan Kompetensi Dosen LPTK di era Industri 4.0

\section{LANDASAN TEORI}

Pengertian dosen dalam tulisan ini merujuk pada definisi dosen berdasarkan UU No 14 Tahun 2005 tentang guru dan dosen, yaitu dosen dipandang sebagai pendidik profesional dan ilmuwan dengan tugas utama 
mentransformasikan, mengembangkan, dan menyebarluaskan ilmu pengetahuan, teknologi, dan seni melalui pendidikan, penelitian, dan pengabdian kepada masyarakat.

Era Industri 4.0 yang dimaksud dalam tulisan ini adalah istilah yang digunakan untuk merujuk pada era dimana terjadi perpaduan teknologi yang mengakibatkan dimensi fisik, biologis, dan digital sulit untuk dibedakan (Scawab, 2016). Era Industri 4.0 ditandai dengan terjadinya digitalisasi dan pemanfaatan kecerdasan buatan (Artificial Intelligence) secara massif di berbagai sektor kehidupan manusia, terutama di bidang ekonomi (Scawab, 2016).

\section{METODE}

Kajian ini merupakan kajian literatur terkait dengan tantangan dosen di era Industri 4.0. Literatur tersebut dikupas secara mendalam dan dibahas kembali dalam dua sub bahasan, yaitu pertama mengupas tentang tantangan dunia Pendidikan Tinggi di Indonesia pada era Industri 4.0, dan kedua tentang kompetensi Dosen PTKI di era Industri 4.0.

\section{HASIL DAN PEMBAHASAN}

\section{A. Tantangan dunia Pendidikan Tinggi di Indonesia pada era Industri} 4.0

Saat ini, Indonesia berupaya membangun sistem pendidikannya, baik dari kurikulum, sumber daya manusia, maupun manajemen pendidikannya. Namun dari segi mutu, sistem pendidikan di Indonesia perlu adanya perubahan untuk sejajar dengan sistem pendidikan di negara maju serta mengatasi tantangan dunia pendidikan pada era industri 4.0 .

Tantangan dunia Pendidikan Tinggi di Indonesia pada era Industri ini mengacu pada harapan untuk memiliki perguruan tinggi kelas dunia dan dapat bertahan serta berkembang dari dampak perubahan yang 
muncul dikarenakan inovasi dalam sains dan teknologi yang terjadi dalam setiap komponen masyarakat.

Pada saat ini, sistem pendidikan tinggi di Indonesia sedang menghadapi perubahan yang perlahan, contohnya sistem yang berlaku masa lalu mengalami perubahan sehingga memunculkan sistem pendidikan baru yang pada akhirnya akan mengubah keseluruhan sistem pendidikan di Indonesia, karena upaya perubahan tersebut menjawab kebutuhan serta menyempurnakan sistem pendidikan tinggi untuk menjawab tantangan zaman.

Yusuf Qardawi mengungkapkan sejarah mengajarkan bahwa peradaban adalah siklus, dan waktu yang akan terus bergulir, perubahan merupakan keniscayaan dan tetapnya keadaan adalah impossibility, absurdity (Abdullah dkk. 2003). Dan ini merupakan sebuah hukum yang mutlak dan tidak dapat dielakkan.

Samuel Hutington mengungkapkan sebuah teori yakni yang bertahan adalah yang paling berkualitas bukan yang paling kuat, karena yang paling kuat merupakan hukum rimba, sedangkan teori yang bertahan adalah yang paling berkualitas dalam hal ini merupakan hukum (insani) manusia (Abdullah dkk. 2003).

Artinya kesiapan Perguruan Tinggi di Indonesia dalam menghadapi tantangan baik internal maupun eksternal, baik dalam skala lokal (nasional) maupun global (internasional) harus diwujudkan sebagai upaya dalam menciptakan Sumber daya Manusia (Dosen) serta output (mahasiswa dan Lulusan) yang berkualitas sehingga mendorong Perguruan Tinggi di Indonesia menjadi Perguruan Tinggi yang mampu bersaing dalam kanca Internasional.

Tantangan perguruan tinggi untuk dapat berkembang pada masa industri ini tidak dapat dipisahkan dari dukungan negara dan masyarakat. Karena, perguruan tinggi tidak dapat berkembang sendiri dan terlepas dari keadaan masyarakat di sekitarnya. Contohnya dalam 
mengembangkan kegiatan perlu diperhatikan apakah yang direncanakan untuk diterapkan hasilnya berguna bagi masyarakat. Maka makin tinggi tingkat perkembangan masyarakat, makin banyak pula yang diharapkan dari keberadaan perguruan tinggi.

Dengan demikian, misi utama perguruan tinggi ada dua. Pertama, memberikan pemahaman dan mengembangkan ilmu, khususnya ilmuilmu dasar, yaitu ilmu-ilmu yang tidak langsung memiliki kegunaan praktis, namun diperlukan dalam pengembangan berbagai ilmu menuju masa depan, terutama dalam aspek terapannya. Kedua, menghasilkan lulusan terdidik untuk mengisi berbagai peran dalam negara modern. Untuk dapat menjalankan kedua misi itu, perguruan tinggi memerlukan staf pengajar dan peneliti bermutu (dosen) dalam jumlah yang memadai, lengkap dengan berbagai fasilitas penunjangnya, sehingga tercipta lingkungan akademik yang menyokong pelaksanaan misi (Abdullah dkk. 2003).

Pada era industri ini adanya kecenderungan kuat yakni terjadinya daya saing (pasar) yang melanda seluruh komponen kehidupan manusia. Salah satu implikasi era ini terlihat dengan adanya persaingan antar Perguruan Tinggi dalam hal kemajuannya. Maka dalam hal ini peran pendidik (dosen) ialah mendidik peserta didik (mahasiswa) agar menjadi mahasiswa yang mengikuti perkembangan zaman tanpa meninggalkan akar budaya, serta menjembatani kepentingan-kepentingan yang terkait, agar output Pergurun tinggi tidak terpental atau terasing pada era disrupsi dan industri 4.0 ini.

\section{B. Kompetensi Dosen PTKI di era Industri 4.0}

Pada era industri 4.0, pendidikan tinggi dituntut untuk dapat mengatasi gejolak perubahan yang terjadi dikarenakan transformasi digital. Salah satu komponen yang dapat mengatasi gejolak tersebut ialah sumber daya manusia yang ada di perguruan tinggi, dalam hal ini dosen (tenaga pendidik). Dosen pada era industri dituntut perlu mempunyai 
kualifikasi dan kompetensi yang dapat bersaing dan bertahan dalam gejolak era industri 4.0 ini.

Robert Houston mendefinisikan kompetensi sebagai “competence is adequacy for a task or as possesion of required knowladge, skill and abilities" (Arifin, 1991). Dapat diartikan bahwa Houston mendefinisikan kompetensi sebagai kemampuan yang memadai untuk melakukan tugasnya atau memiliki pengetahuan, keterampilan dan kecakapan yang dipersyaratkan untuk itu. Sedangkan Uno (2008) memandang kompetensi mengacu pada kemampuan seseorang melaksanakan sesuatu, yang kemampuan itu diperoleh melalui pelatihan atau pendidikan. Lebih lanjut, menurut Majid (2007) kompetensi merupakan seperangkat tindakan intelegen dan penuh tanggung jawab yang harus dimiliki seseorang sebagai syarat untuk dianggap mampu melaksanakan tugas-tugas dalam bidang pekerjaan tertentu.

Dari berbagai macam definisi sebagaimana diuraikan, dapat dipahami bahwa kompetensi merupakan perpaduan dari penguasaan nilai-nilai dan sikap yang direfleksikan dalam kebiasaan berpikir dan bertindak dalam suatu tugas pokok dan fungsinya. Kompetensi juga berkenaan dengan kecakapan seseorang dalam melaksanakan tugas pokok dan fungsinya untuk mecapai standar mutu dalam kinerja atau hasil kerja nyata.

Dengan kata lain, kompetensi dapat diartikan sebagai kemampuan manusia dalam bidangnya atau profesinya. Karena profesi merupakan suatu bidang pekerjaan atau keahlian tertentu yang mensyaratkan kompetensi intelektualitas, sikap, dan keterampilan tertentu yang diperoleh melalui proses pendidikan secara akademis yang intensif (Rusman, 2016).

Dalam konteks ini, kompetensi yang sekiranya perlu ada di dalam diri Dosen tanpa kecuali pada dosen PTKI di era industri 4.0 ini, ialah kompetensi yang mampu mengatasi gejolak perubahan, serta mampu 
menerapkan perubahan (inovasi) tersebut dalam setiap pekerjaannya.

Uraian di atas menegasikan, bahwa dosen sebagai salah satu pilar penting dalam perguruan tinggi memegang peranan strategis bagi pendidikan tinggi dalam menghadapi era digitalisasi dan Revolusi Industri 4.0. Menteri Riset, Teknologi dan Pendidikan Tinggi Mohamad Nasir dalam Pengarahan tentang Dampak Revolusi Industri 4.0 di Universitas Diponegoro Semarang mengatakan untuk menghasilkan lulusan yang memiliki daya saing tinggi dan siap berkompetisi di era Industri 4.0 dibutuhkan dosen yang memiliki kompetensi inti keilmuan (core competence) yang kuat, mempunyai soft skill, 'critical thinking', kreatif, komunikatif dan mampu berkolaborasi dengan baik dengan mahasiswa (Natsir, 2018).

Pada era industri 4.0 ini menuntut Kualifikasi dan Kompetensi Dosen menjadi sebuah pekerjaan yang cukup sulit dan membutuhkan profesionalitas dosen itu sendiri. Karena dosen merupakan pekerjaan profesional, yang bertugas dalam hal menjawab tantangan perguruan tinggi pada era industri.

Jika dilihat syarat-syarat atau ciri pokok dari pekerjaan profesional meliputi: pertama, Pekerjaan profesional ditunjang oleh suatu ilmu tertentu secara mendalam yang hanya mungkin diperoleh dari lembaga-lembaga pendidikan yang sesuai, sehingga kinerja didasarkan kepada keilmuan yang dimilikinya yang dapat dipertanggung jawabkan secara ilmiah; kedua, Suatu profesi menekankan kepada suatu keahlian dalam bidang tertentu yang spesifik sesuai dengan jenis profesinya, sehingga antara profesi yang satu dengan yang lainnya dapat dipisahkan secara tegas; ketiga, Tingkat kemampuan dan keahlian satu profesi didasarkan kepada latar belakang pendidikan yang dialamaminya yang diakui oleh masyarakat, sehingga semakin tinggi latar belakang pendidikan akademik sesuai dengan profesinya, semakin tinggi pula tingkat keahliannya, dengan demikian semakin tinggi pula tingkat 
penghargaannya; keempat, Suatu profesi selain dibutuhkan oleh masyarakat juga memiliki dampak terhadap sosial kemasyarakatan, sehingga masyarakat memiliki kepekaan yang sangat tinggi terhadap setiap efek yang ditimbulkannya dari pekerjaan profesinya itu (Sanjaya, 2013).

Dapat disimpulkan bahwa dosen profesional seharusnya mempunyai ciri-ciri yakni: pertama,dosen profesional ialah dosen mempuyai suatu keahlian (mengajar, meneliti dan pengabdian masyarakat) sesuai dengan keilmuan yang dimilikinya sehingga dapat dipertanggung jawabkan secara ilmiah; kedua, Tingkat kemampuan dan keahlian dosen didasarkan kepada latar belakang pendidikan yang ditempuhnya.

Kualitas perguruan tinggi tidak dapat dipisahkan dari kualitas dosennya. Demikian juga kualitas dosen akan menentukan kualitas lulusan maupun kualitas riset yang dihasilkan oleh perguruan tinggi tersebut, maka karaktersitik tugas utama seorang dosen meliputi: pertama, mengajar, yang di dalam prosesnya bukan hanya menyampaikan materi, akan tetapi merupakan pekerjaan yang kompleks, oleh sebab itu maka dalam pelaksanaannya, diperlukan sejumlah keterampilan khusus yang didasarkan pada konsep dan ilmu pengetahuan yang spesifik;kedua, memiliki keahlian yang jelas, yakni mengantarkan peserta didik kearah tujuan yang diinginkan; ketiga, luasnya pengetahuan dan keterampilan, dalam hal ini bukan hanya menguasai materi ajar, tetapi juga memahami rumpun ilmu yang lainnya; keempat, mempunyai kepribadian sosial yang tinggi;kelima, Pekerjaan pendidik (dosen) merupakan pekerjaan yang dinamis, yang selamanya harus sesuai dan menyesuaikan dengan perkembangan ilmu pengetahuan dan teknologi. Oleh karena itu pendidik (dosen) harus peka terhadap dinamika perubahan dan perkembangan yang pasti berubahubah, baik perkembangan sosial, budaya, politik dan teknologi (Sanjaya, 
2013).

Lebih lanjut jika melihat perkembangan era industri 4.0 ini, yang menekankan gelombang besar transformasi digital, maka hanya ada dua pilihan yang dapat dilakukan dosen dalam menghadapai era industri ini, yakni meliputi: pertama, tidak melakukan apa-apa yang pada akhirnya bermuara pada jurang kehancuran akibat disrupsi; kedua, mempunyai langkah strategis untuk mengantisipasi dan merespon gelombang disrupsi.

Dapat dipahami bahwa jika pendidik dalam hal ini dosen tidak memiliki kesiapan digital maka akan bermuara pada kehancuran, sedangkan jika dosen memiliki kesiapan dalam hal transformasi digital dengan memanfaatkan teknologi digital dan menerapkannya pada setiap kinerjanya seperti pembelajaran, penelitian serta pengabdian masyarakat (Tri Dharma Perguruan Tinggi), maka antisipasi dan respon tersebut dapat mengendalikan gelombang disrupsi, sehingga teknologi digital membantu meningkatkan kinerja kompetitif dosen.

Dalam menerapkan langkah strategis untuk mengantisipasi dan merespons perubahan sistem pendidikan di era industri ini, maka perlunya perubahan penerapan sistem pada perguruan tinggi ke arah transformasi digital. Selain kompetensi inti, dosen juga dituntut mempunyai sebuah kualifikasi dan kompetensi pendukung yakni meliputi: kelincahan, inovasi, kreativitas, antisipasi, eksperimen, keterbukaan pikiran, dan networking (jejaring).

Pertama, Dalam hal kelincahan, dosen dituntut untuk tersus menerus bertransformasi dan bereksperimen sehingga dapat menghasilkan ide-ide pembelajaran yang baru. Kedua, Dalam hal inovasi, dosen dituntut mempunyai kapasitas dalam menerjemahkan ide atau temuannya menjadi suatu daya cipta yang bernilai. Inovasi tersebut dapat berupa produk atau layanan baru untuk pola pembelajaran mahasiswa, proses pembelajaran masa kini, atau inovasi yang 
menghasilkan keunggulan kompetitif yang baru.

Ketiga, dosen dituntut untuk mempunyai kreativitas, sehingga dapat mengubah sebuah ide atau imajinasi menjadi sesuatu yang baru. Dalam hal ini dosen diharapkan mampu melihat sesuatu dengan cara baru, menemukan pola yang menarik dan baru, ataupun mengkoneksikan hal lama dan hal baru sehingga memunculkan produk yang lebih baik.

Keempat, dosen hendaknya bisa mengantisipasi gejolak perubahan di era industri digital ini. Maka dosen diharapkan mempunyai kapasitas dalam mengantisipasi dan bertindak secara cepat dalam kondisi apapun. Dengan adanya kemampuan antisipasi ini, maka dosen dapat cepat merespon, beradaptasi, dan menjadikan peluang untuk memenangkan gejolak perubahan dunia industri digital.

Kelima, pada era industri 4.0 ini, dosen diharuskan mampu bereksperimen atau mempunyai kemauan untuk mencari dan mencoba sesuatu yang baru yang terkait dengan kemajuan teknologi digital dan selalu mengedepankan semangat dalam merespons perkembangan teknologi digital. Keenam, dosen hendaknya mempunyai keterbukaan pikiran sehingga mempunyai kapasitas untuk membuka diri dan menerima segala kemungkinan yang ditawarkan oleh kemajuan teknologi digital, karena langkah awal sebuah transformasi digital ialah adanya kesadaran dan sikap membuka diri terhadap berbagai potensi, ancaman, dan peluang yang muncul akibat kemajuan teknologi digital.

Ketujuh, Dosen pada era industri ini hendaknya mempunyai network (jaringan) yang luas demi menunjang kinerja dan kompetensinya. Maka seorang dosen hendaknya mempunyai relasi dan dan mampu bekerja sama dengan seluruh stakeholders.

Dari ketujuh syarat tersebut dapat dipahami bahwa untuk mengatasi era industri 4.0 , maka kualifikasi dan kompetensi dosen yang wajib ada ialah pertama, pengetahuan digital, dalam hal ini dosen 
mengenal mengenai aplikasi digital; kedua, pengalaman digital, dalam hal ini dosen dituntut mempunyai pengalaman dalam menggunakan aplikasi-aplikasi yang berbasis digital dalam setiap pekerjaannya

Jika melihat kembali pada masa lampau, sistem pembelajaran di perguruan tinggi hanya menggunakan metode ceramah, dengan media menulis di papan tulis, dan ada pula sebagian dosen menyampaikan materi perkuliahan menggunakan media plastik transparansi kemudian menyorotkannya ke layar dengan menggunakan OHP (overhead projector), para mahasiswa mencatat materi tersebut di buku catatan masing-masing menggunakan bolpoin. Tetapi pada era industri saat ini, kini dosen membagikan materi pelajaran menggunakan e-mail atau slideshare, kemudian di kelas ia menyampaikan materi menggunakan proyektor yang terhubung dengan komputernya dan tiap mahasiswa membawa leptop untuk mengetik catatan dari materi yang disampaikan dosen dan bahkan menggunakan pola pembelajarn e-learning (Rudito \& Sinaga, 2017). Fenomena seperti inilah sebuah contoh bahwa perubahan dan perkembangan dunia pendidikan kita telah mencapai puncak era industri 4.0 dikarenakan tranformasi digital.

Era saat ini telah di ramalkan oleh seorang fisikawan yakni Albert Einsten yang menyatakan bahwa " The cosmic religius experience is the strongest and the nobelst main spring of scientific research. Maksudnya ialah mencoba merekonstruksi paradigma keterpaduan ilmu pengetahuan dan teknologi (Iptek) (Abdullah dkk, 2003). Dapat disimpulkan bahwa Einsten meyakini bahwa terdapat keterpaduan antara ilmu pengetahuan dan teknologi, dan pada era inilah Iptek tersebut akhirnya dapat bersanding sehingga pendidikan era ini merupakan pendidikan yang menerapkan sistem digital.

Manfaat teknologi informasi dan komunikasi bagi dunia pendidikan yakni: akses ke perpustakaan secara online, akses ke pakar, perkuliahan secara online, menyediakan layanan informasi akademik 
suatu institusi pendidikan, menyediakan fasilitas mesin pencarian data, menyediakan fasilitas diskusi, menyediakan fasilitas direktoriat alumni dan institusi , serta menyediakan fasilitas kerja sama (Darmawan, 2013).

Information Technology (IT) memberikan kontribusi yang luar biasa dalam hal penyebaran materi informasi ke seluruh belahan dunia. IT merupakan media dan merupakan salah satu instrumen yang bersifat massal dan melibatkan ribuan bahkan miliyaran manusia. Hanya dengan berada di depan komputer maupun handphone yang terhubung dengan internet, seseorang bisa terhubung ke dunia virtual global untuk mendapatkan ataupun menyebarkan informasi dalam satu waktu.

Ditengah kemelut dunia pendidikan Indonesia yang tidak kunjung selesai, kehadiran teknologi informasi menjadi satu titik cerah yang diharapkan mampu memberi sumbangan positif dalam meningkatkan mutu pendidikan.

Salah satu produk integrasi teknologi informasi ke dalam dunia pendidikan adalah e-learning atau pembelajaran elektronik. Saat ini $e$ learning mulai mengambil perhatian banyak pihak, baik dari kalangan akedemisi, profesional, perusahaan maupun industri. Di institusi pendidikan tinggi, e-learning telah membuka pemahaman baru dalam hal proses belajar mengajar. Dalam era industri e-learning dinilai mampu membantu proses meningkatkan kompetensi mahasiswa.

Penjelasan di atas dapat dimaknai bahwa para dosen di PTKI dituntut harus mampu beradaptasi terhadap Revolusi Industri 4.0. Salah satu sikap adaptif itu dengan mengikuti perkembangan teknologi dalam penerapan pola pembelajaran, pola pembelajaran konvensional tidak bisa lagi dipertahankan, sehingga mampu menghasilkan lulusan berdaya saing tinggi. Dengan begitu PTKI untuk senantiasa meningkatkan kapasitas dan kapabilitas dosen yang dimilikinya. Dalam menghadapi revolusi industri dosen juga harus mengikuti program kompetensi inti yang sesuai dengan kebutuhan revolusi industri 4.0. 
Direktorat Pendidikan Tinggi Islam seyogyanya menyiapkan berbagai kebijakan strategis untuk penyiapan platform kualifikasi yang memenuhi kompetensi inti yang dibutuhkan oleh perkembangan industri 4.0 , program studi, kurikulum, kelembagaan serta penyediaan beasiswa magister dan doktoral bagi dosen PTKI yang relevan dengan perkembangan revolusi industri 4.0.

Bila berkaca dan merujuk pada kebijkan Kemenristekdikti ada lima elemen penting yang harus dilaksanakan direktorat PTKI untuk mendorong daya saing PTKI dalam kanca global di era Revolusi Industri 4.0, yakni:

1. Persiapan sistem pembelajaran yang lebih inovatif di perguruan tinggi seperti penyesuaian kurikulum pembelajaran, dan meningkatkan kemampuan mahasiswa dalam hal data Information Technology (IT), Operational Technology (OT), Internet of Things (IoT), dan Big Data Analitic, mengintegrasikan objek fisik, digital dan manusia untuk menghasilkan lulusan perguruan tinggi yang kompetitif dan terampil terutama dalam aspek data literacy, technological literacy and human literacy.

2. Rekonstruksi kebijakan kelembagaan pendidikan tinggi yang adaptif dan responsif terhadap revolusi industri 4.0 dalam mengembangkan transdisiplin ilmu dan program studi yang dibutuhkan. Selain itu, mulai diupayakannya program Cyber University, seperti sistem perkuliahan distance learning, sehingga mengurangi intensitas pertemuan dosen dan mahasiswa. Cyber University ini nantinya diharapkan menjadi solusi bagi anak bangsa di pelosok daerah untuk menjangkau pendidikan tinggi yang berkualitas.

3. Persiapan sumber daya manusia khususnya dosen dan peneliti serta perekayasa yang responsive, adaptif dan handal untuk menghadapi revolusi industri 4.0. Selain itu, peremajaan sarana prasarana dan pembangunan infrastruktur pendidikan, riset, dan inovasi juga perlu 
dilakukan untuk menopang kualitas pendidikan, riset, dan inovasi.

4. Terobosan dalam riset dan pengembangan yang mendukung Revolusi Industri 4.0 dan ekosistem riset dan pengembangan untuk meningkatkan kualitas dan kuantitas riset dan pengembangan di Perguruan Tinggi, Lembaga Litbang, LPNK, Industri, dan Masyarakat.

5. Terobosan inovasi dan perkuatan sistem inovasi untuk meningkatkan produktivitas industri dan meningkatkan perusahaan pemula berbasis teknologi.

\section{KESIMPULAN}

Dengan demikian maka tantangan dosen PTKI pada era industri 4.0 yakni; pertama, mengetahui penggunaan digital serta menerapkannya, contohnya mendidik/ mengelola pembelajaran berbasis internet dan pembelajaran elektronik (e-learning) sebagai skil utama pada era ini; kedua, kompetensi kepemimpinan yang mengarahkan mahasiswa memiliki pengetahuan teknologi; ketiga, mempunyai kemampuan memprediksi dengan tepat arah gejolak perubahan dan langkah strategis menghadapinya; keempat, mempunyai kompetensi dalam mengendalikan diri dari segala gejolak perubahan, dan mampu meenghadapinya dengan memunculkan ide, inovasi, serta mempunyai kreativitas.

\section{DAFTAR PUSTAKA}

(2017) Era Disrupsi Peluang dan Tantangan Pendidikan Tinggi Indonesia, Akademi Ilmu Pengetahuan Indonesia: Jakarta.

Abdullah, Muhammad Amin dkk, (2003) Menyatukan Kembali Ilmu-Ilmu Agama dan Umum Upaya Mempertemukan Epistemologi Islam dan Umum, SUKA-Press: Yogyakarta.

Arifin, HM. (1991) Kapita Selekta Pendidikan: Islam dan Umum, Jakarta: Bumi Aksara.

Darmawan, Deni (2013) Teknologi Pembelajaran, PT Remaja Rosdakarya: 
Harto, K. (2018). TANTANGAN DOSEN PTKI DI ERA INDUSTRI 4.0. Jurnal Tatsqif, 16(1), 1-15. Retrieved from http://journal.uinmataram.ac.id/index.php/tatsqif/article/view/159

Bandung

Kasali, Renald (2018) Disruption “Tak Ada Yang Tak Bisa Diubah Sebelum Dihadapi Motivasi Saja Tidak Cukup"Menghadapi Lawan-Lawan Tak Kelihatan dalam Peradaban Uber, PT Gramedia Pustaka Utama: Jakarta.

Majid, Abdul (2007) Perencanaan Pembelajaran Mengembangkan Standar Kompetensi Guru, Cet III, Bandung: PT Remaja Rosdakarya.

Rudito, Priyanto dan Mardi F.N. Sinaga (2017) Digital Mastery Membangun kepemimpinan Digital Untuk Memenangkan Era Disrupsi, Pt Gramedia Pustaka Utama: Jakarta.

Rusman (2016) Model-Model Pembelajaran, PT Raja Grafindo Persada: Jakarta.

Sanjaya,Wina (2013) Strategi Pembelajaran Berorientasi Standar Proses Pendidikan, Kencana Prenadamedia Group:Jakarta.

Schwab, Klaus (2016) The Fourth Industrial Revolution: what it means, how to respond. Disadur dari https://www.weforum.org/agenda/2016/01/ the-fourth-industrial-revolution-what-it-means-and-how-torespond/

Uno, Hamzah B. (2008) Profesi Kependidikan Problema, Solusi, dan Reformasi Pendidikan di Indonesia, Cetakan III Jakarta: Bumi Aksara. 